\title{
The urban land debate in the global South: new avenues for research
}

\section{Griet Steel, Femke van Noorloos, Christien Klaufus}

LANDac and International Development Studies, Dept. Human Geography \& Planning, Faculty of Geosciences, Utrecht University, P.O. Box 80.115, 3508 TC Utrecht, The Netherlands

Author manuscript published as article in Geoforum 83, 2017, p. 133-141, https://doi.org/10.1016/j.geoforum.2017.03.006 Part of special issue "From land grabs to inclusive development?"

(C) 2017. This manuscript version is made available under the CC-BY-NC-ND 4.0 license http://creativecommons.org/licenses/by-nc-nd/4.0/

\section{Keywords}

Urbanization

Land commodification

Gentrification

Speculative urbanism

Land governance

Global South

\begin{abstract}
The global 'land grab' debate is going urban and needs a specific conceptual framework to analyze the diverse modalities through which land commodification and speculation are transforming cities across the globe. This article identifies new avenues for research on urban land issues by drawing on an extensive body of academic literature and concrete cases of urban land transformations in Asia, Latin America and Africa. These transformations are analyzed by focusing on three types of urban investments - investments in property, investments in public space and public services, and investments in speculation, image building and 'worlding' - and the way these investments are intermingled with and enhanced by processes of gentrification and speculative urbanism. Addressing real estate and infrastructure investments, speculation and gentrification through a land-based lens allows us to deepen the discussion on urban land governance in the global South. We argue that urban land acquisition cannot be thoroughly understood in isolation from the workings of urban real estate markets, public policies, and displacement processes. The urban land grab debate needs to consider the dialectic interplay between land use change and general socio-spatial transformations both in central - or recentralized - and peripheral areas. This is why we plea for a kaleidoscopic perspective on urban land governance by uncovering the complex patchwork of urban land acquisitions and their diverse temporalities and spatialities, their hybrid character in terms of actors involved, and the multiple and often unpredicted ways in which urban dwellers try to gain control over and access to urban land.
\end{abstract}




\section{Introduction}

The urban transition that is currently under way in Africa and Asia has urged scholars in the political economy of land markets to shift focus from rural land governance to urbanization. One of the academic debates in which increasing attention is paid to urban land markets is the 'land grab' debate. Originally concerned with massive land acquisitions in rural areas in the global South, scholars progressively assess the impact of large-scale land deals in cities (Zoomers et al., 2017). The debate on the effects of the rural global land grab focuses on externally driven and large-scale land investments fueled by the global food-fuel-energy crises as well by broader developments such as climate change policy; it is also dominated by notions of direct and indirect displacement, enclosure of the commons and food insecurity. Policy discussions on land grabs often evolve around land administration and formalization, the recognition of customary land rights; compensation and resettlement (and the lack thereof); and participation and free, prior and informed consent (see other articles in this special issue).

Whereas the rural land grab debate traditionally focuses on large-scale land acquisitions of at least 200 hectares (Zoomers, 2010), it is increasingly taking into account the effects of a multiplicity of smaller land deals and the involvement of a large variety of actors, including domestic and smaller scale investors (Zoomers and Kaag, 2014; Hilhorst et al., 2011). This also means that urban processes of land-based transformation are slowly gaining increased traction in the debate, which is arguably also fueled by the renewed dominance of urban policy agendas (Parnell, 2016). However, the urban land grab tends to be more fragmented, gradual and therefore less visibly-outstanding than most of the rural examples. It includes a patchwork of different activities - ranging from land use change to regeneration and redevelopment as well as to new-built and commercial gentrification - with the common objective to appropriate land and to increase its value.

One important difference between rural and urban land grab debates is that discussions over urban land easily conflate with debates over new urban reconfigurations and gentrification processes, or what is often referred to as the urban transition (Shin et al., 2016). Hence, urban land acquisition cannot be thoroughly understood in isolation from the workings of urban real estate markets, public policies, and displacement processes. The urban land grab debate needs to consider the dialectic interplay between land use change and general socio-spatial transformations both in central - or recentralized - and peripheral areas. At the same time the concept of gentrification is not precise enough to interpret the variety of current exclusionary urban processes and the important role that land plays in these developments. While the gentrification debate primarily addresses processes that take place on a given urban surface, the land grab debate aims to understand urban transformation processes specifically through the lens of land-related dynamics.

Since the urban transition is more and more acknowledged as an important source of land transformation, it is important to find out what 'inclusive' development means in this context. Defining and measuring inclusive development in the context of land deals might become even more complex in an urban or urbanizing context: the myth of homogeneous and territorially fixed 'local communities' is easily debunked, and a variety of populations - with various degrees of mobility and diverse interests - make meaningful participation and benefit sharing challenging. In addition, understanding land investments in (peri-)urban contexts requires looking into the long term processes of urban change and the more indirect modalities of displacement and land grabbing, which make it even more complex for urban and peri-urban dwellers to demand their right to the city. 
Urbanization rates in the global South demonstrate an urgent need for the careful mapping of both urban land and real estate sectors in and around urban areas and for broadening the scope of the original land grab debate to include (peri-) urban processes. Hereby we aim to shape the outline for the 'urban turn' of the land-grab debate, in which a comparative perspective is central. We depart from this perspective based on the plea that has become louder over the last decade for comparative urbanism on the basis of urban notions that stem from cities in the global South.

This article reviews some of the primary academic findings on urban land transformations in the global South by exploring land acquisitions, capital-driven evictions and displacements in urban or emerging urban areas, speculative urbanism as well as the unintended processes of gentrification. It specifically focuses on the processual features of the urban land grab in order to identify new avenues for research on urban land investment and their issues of inclusiveness and participation, and to broaden the discussion of well-studied rural land transformations. Drawing on an extensive body of academic literature on the urban land debate in Asia, Latin America and Africa, the article provides an in-depth understanding of the diverse modalities through which land commodification and speculation are transforming cities across the globe. Studies from each continent are used to complement the debate on the urban land grab. We ask: How can the concepts of gentrification, speculative urbanism and world city making enhance the urban land debate and bring more complexity into thinking about inclusive development and participation? To what extent is speculative urbanism - a concept derived from studies on urban developments in Asia - also useful toward understanding new urban developments in Africa and Latin America? Finally, how can gentrification - a concept more often applied in a Latin American context - be a way to analyze local socio-spatial consequences in cities in Asia and Africa?

We engage with these questions throughout the next sections of the article. We start with a brief overview of urbanism in Asia, Africa and Latin America and by identifying diverse processes of urban transitions and land transformations in and across the continents. Afterwards we reflect upon the concepts of land use change, gentrification, and speculative urbanism which come into place when we zero in on the specific dynamics of urban land grabs, changing land values in cities in the global South and their meanings in terms of urban land governance. In the discussion we analyse these urban dynamics by focusing on three types of urban investments - investments in property (land or real estate), investments in public space and public services, and investments in speculation, image building and worlding. In the conclusion we reflect upon our findings and their meaning in terms of inclusive development and sustainable urban growth.

\section{Urbanism and land transformations throughout the global South}

As the global urban transition is well underway, rapid urbanization in the global South is gaining increased exposure and thus inviting both interest and concern. Indeed, Africa and Asia are urbanizing faster than any other region. In fact, until 2050 nearly $90 \%$ of urban population increase will be concentrated in these regions; by 2050, 56\% and $64 \%$ of the respective populations of Africa and Asia are projected to live in urban areas (UN DESA, 2014). Meanwhile, Latin America and the Caribbean are already largely urbanized with about 80 per cent currently living in cities (ibid.). As it is known to be the region where the 'first' urban transition is now completed (UN-Habitat, 2012; Klaufus and Jaffe, 2015), it is relevant to consider what could be learned in hindsight from these rapid transition processes. 
In general, increased urbanization is still often seen as a main condition for sustained economic growth, and cities as key sites of capital accumulation. On the other hand, a multitude of social, environmental and institutional problems or even 'crises' are often highlighted when conceptualizing urbanization in the global South (most often expressed in relation to the proliferation of slums). According to the UN World Urbanization Prospects report, "as the world continues to urbanize, sustainable development challenges will be increasingly concentrated in cities, particularly in the lower-middle- income countries where the pace of urbanization is fastest" (UN DESA, 2014: 1). In order to meet the challenge of 'inclusive, resilient and sustainable' cities and to achieve Sustainable Development Goal 11, enormous investments in housing, infrastructure, energy, and economic development are expected to be mobilized over the coming years (Zoomers et al., 2017). This focus on urban development in academic, policy and media circles is on the rise due to the United Nations Conference on Housing and Sustainable Urban Development (Habitat III) and the adoption of the New Urban Agenda.

An increased interest in what has been coined 'planetary urbanization', understood as a worldwide spread of urban forms, lifestyles, mobilities, media, etc., has brought to light the lack of theoretical and methodological clarity in conceptualizations of the urban. The world is increasingly made up of highly differentiated, discontinuous and complex urbanization landscapes, thus making it difficult to delimit urban areas in simple ways or to separate the urban and the rural (Amin and Thrift, 2002; Brenner, 2013; Brenner and Schmid, 2014). At the same time, urbanization and urban transformation processes have created a dominant metanarrative when talking about planetary change. By delving into issues of land governance and land-based transformations and by asking ourselves how a traditionally 'rural' debate can enlighten our understanding of the 'urban', we aim to contribute to a more complex understanding of the spaces commonly classified as rural, peri-urban or urban in spite of their hybridity. Across the globe, globalization, and changing models of urban governance have left their imprint on the urban landscape, especially with regard to changing land use and its social consequences. Land commodification and speculation relate directly to land use change that is enabled by public policies: real estate markets and infrastructural works not only heavily influence ground rents, they also define who can share in the benefits of rising land prices (Smith, 1996; Smolka, 2013).

Sheppard et al. (2015) frame these processes in terms of 'neoliberal urbanization' and 'urban revolutions from above': as part of western urban agendas and ideas, the postcolonial world has moved increasingly towards privatization of public services, urban entrepreneurialism and inter-urban competition as key to economic growth. As global cities imaginaries - or 'world city making' (Roy and Ong, 2011) - have become dominant in urban policy, urban development has been highly influenced by global finance companies, international financial institutions and global consultants, which have actively promoted cities for the rich. Worlding goes hand in hand with image building - the illusion of success projected onto the future - and city branding. The framing of a promising future is key to making people believe in increased land values, whether or not real profits will be realized. Iconic architectural projects are a proven way to establish investor trust (Sklair, 2005). For future users and residents, a project's functional value is fully subordinated to attempts to successfully frame the 'surplus narrative'. Speculative urbanism, largely surging in Asia's rising economies and developmental states, relates to the strong involvement of city governments in devising competitive and speculative urban land strategies meant to attract private investment (Goldman, 2011). Yet, in Latin American and African contexts such speculative and worlding developments are often taking place in different ways and on a smaller scale. Nonetheless, in all three regions these 
processes have in many cases led to forced evictions, dispossessions and housing demolitions, which increasingly lead to protest and resistance (Sheppard et al., 2015). On the other hand, the term 'neoliberal urbanization' seems too broad to adequately capture the complex and variegated relations between the state and the private sector that shape current urbanism in the global South, for example in Asia where city governments play much more active roles. At the very least we should take into account local variations of the term 'neoliberalism' while also recognizing that, in some cases, it might be wholly inadequate after all. In terms of these new urban debates, it is important to draw some very broad strokes to characterize regions across the global South. Indeed, in order to effectively analyze the 'urban turn' of the land-grab debate, a comparative perspective is central. The plea for comparative urbanism, based on urban notions stemming from cities in the global South, has become louder over the last decade. Robinson's (2006) search for 'Ordinary Cities' takes those different forms, scales and contexts into account. McFarlane (2010) adds that an alternative framing of comparisons, not as a methodology but as the focus of attention, articulates with a post-colonial perspective in urban studies. Questioning the impact of comparisons in urban studies, he argues that more attention should be paid to policy mobilities and the role of power in producing such comparisons. Following from there, the ways in which comparisons are contested need to be taken into account as well. The increase in global urban fora and best-practice lists are a case in point. For example the 2014 World Urban Forum in Medellín - where successful policies and best practices were exchanged diplomatically and without sufficient attention for the drawbacks - was heavily contested at the Social Urban Forum held simultaneously in the same city (Ortiz, 2016).

Despite running the risk of oversimplification, it is important to stress some key differences between the regions. First, while the African continent is said to be poised for an enormous boost of urban growth in the coming decades (although much variation exists; see for example Potts, 2012), this is expected to lead to significant challenges. The region is also promoted as a new frontier for global capital (Watson, 2013), yet investments in spectacular and new city projects are taking place on a relatively small scale -especially when compared to the enormous spread of informal settlements. Indeed, African urbanism is often characterized by a lack of formal economic opportunities, the domination of informal settlements and economic activity and a lack of access to basic services; each is often combined with weak state capacities for regulation (see for example Pieterse and Parnell, 2014). Asia also shows many of these characteristics but combines them with stronger state power and influence, especially through the region's developmental states and strong city governments (see for example Goldman, 2011; Li et al., 2014; Shin and Kim, 2016). The latter nevertheless often operates in very neoliberal ways and as such pushes land speculation and displacement of the poor. Asian cities in particular compete globally as 'world cities' by presenting themselves as global knowledge, innovation and production hubs. Combined with large informal sectors and social and environmental problems, this leads to urban spaces that are characterized by large inequalities. This in turn is reminiscent of cities in Latin America and the Caribbean; having also often passed through a more traditional industrialization phase followed in recent decades by a period of neoliberalism, the formal and public sectors have largely given way to more vulnerable informal economies. Many Latin American cities have strong traditions of informal housing and the consolidation or improvement of informal settlements. The region's engagement with the urban question over the longer term has led to much experimentation as well as some of the region's ideas and models currently promoted as 'best practice' around the world (Macedo, 2004, 2013; Bunnell, 2015; Gilbert, 2015). On the other hand, large social inequalities, socio-spatial segregation and related problems of insecurity and crime are haunting the region's cities 
(Roberts, 2005). With these regional differences taken into account, the following sections further analyze the way land speculation and commodification are shaping urbanization processes in the global South. We thereby highlight the differences with the well-studied rural land grab debate.

\section{From rural to urban land grab: some differing focal points}

Since the increase in volume and intensity of large-scale investments in agricultural land became known as the 'global land rush' or 'land grab', the definitions of so-called land grabbing have been very much contested (Holmes, 2014). Generally, the term refers to the buying or leasing of large tracts of land overseas (particularly in the global South) by domestic and transnational companies, governments and individuals; driven by changing commodity prices, these transactions mainly concern the production of food and biofuels (Gudynas, 2008). These largescale land acquisitions produce asymmetric power relations between those gaining control over land use and land value, and other parties involved. As such they have the negative connotation of being a 'grab' (Margulis et al., 2013). Indeed the transfer of property and resources - where local control is passed to more powerful 'outsiders' - is an important feature in defining land grabs (Holmes, 2014).

Table 1: rural versus urban land grabs

\begin{tabular}{|c|c|c|}
\hline & Rural & Urban \\
\hline Type of 'grab' & Land & Land and real estate \\
\hline Effects on & Livelihood & Housing, livelihood \\
\hline Commodity & $\begin{array}{l}\text { Natural resources } \text { (forest } \\
\text { carbon, food and non-food } \\
\text { crops, metals, etc.) }\end{array}$ & $\begin{array}{l}\text { High-end residential areas } \\
\text { (gated communities) } \\
\text { Commercial services (shopping } \\
\text { centers, offices) } \\
\text { Infrastructure }\end{array}$ \\
\hline Scale & Megadeals (more than 200ha) & Dispersed/ fragmented deals \\
\hline Actors & $\begin{array}{l}\text { Foreign individuals, } \\
\text { companies, state agencies. } \\
\text { Increased attention to the } \\
\text { roles of domestic and smaller- } \\
\text { scale investors. }\end{array}$ & $\begin{array}{l}\text { Transnational elites, public- } \\
\text { private partnerships, with } \\
\text { foreign as well as national } \\
\text { companies, individuals, state } \\
\text { agencies }\end{array}$ \\
\hline Processes & Land acquisition & $\begin{array}{l}\text { Land use change, land } \\
\text { development or redevelopment }\end{array}$ \\
\hline
\end{tabular}

Some of these key characteristics of rural land grabs take a slightly different form in an urban context (see table 1). Issues of access and control are key in urban debates as well, but in urban cases there is no unilineal transfer of local control over land towards more powerful outsiders. Urban land acquisitions or changes in urban land use that result in 'grabs' generally involve a variety of actors; as a result, the role of public policies in allowing or enhancing land use change cannot be ignored. Commercial investors are not always established companies and the complex role of transnational elites, for instance, is crucial in understanding manifestations of urban land grabbing and speculative urbanism. Besides their important roles as potential consumers or investors in 'world city' projects, transnational institutions, consultants and diasporas play very active roles in promoting speculative urbanism. This is the case in Bangalore where 
international finance institutions and donors, international NGOs and Indian diasporas living abroad promote world city agendas together with national state officials and business elites (Goldman, 2011). In a world where urban models and 'best practices' are increasingly circulating (Roy and Ong, 2011; Bunnell, 2015), such transnational actors are also increasingly present in Africa and Latin America, and often promoting a variety of land-based investments and redevelopments. Hence where the rural land grab debate focuses on transnational elites in somewhat limited terms (i.e., as investors in rural land), urban examples show us how important it is to scrutinize their much more diverse and complex roles in urban land debates.

In terms of scale, urban land grabs might be less immense. While the specific contexts of urban scaling vary much across continents, in general urban land acquisitions take place on a smaller scale and are more fragmented, gradual and dispersed across the city and therefore are less visible than most rural examples. This does not mean that the impact is less radical or tangible than in urban areas; in some cases land acquisition for peri-urban development is as radical in its forms and impacts as those in rural areas. Yet, in some cases land acquisition for the development of peri-urban areas is as radical in its forms or impact as it is in rural areas. Through immense value increases in urban land and real estate, individual residents and small scale enterprises are no longer able to compete with big multinationals and foreign investors. For low-income groups, rising land and real estate prices make access to housing in central urban areas evermore problematic. As such, our attention should go beyond large-scale 'new city' projects and mega-events alone: fragmented neoliberal urbanism is still very common, for example in many of Latin America's small and medium-sized cities (Klaufus, 2010). New conceptualizations of gentrification - including the gentrification of commerce (Bromley and Mackie, 2009) - are helpful here to make sense of the indirect and sometimes unintended consequences of urban land investments and governance for specific urban groups such as youth and elderly urban dwellers.

As shown in Table 1, we argue that issues related to land tenure in cities are always directly related to the housing question, and hence, indirectly to livelihoods. In rural areas, land as a prerequisite for rural livelihoods is key, regardless of the provision of housing. For large parts of the urban population, rising land prices directly influence the access to affordable and well-located housing for large parts of the population. Indeed, as Soja (2010) has stated, spatial justice is an integral part of social justice and the role of access to land is crucial in this debate. Traditionally, the urban land debate has focused on securing land rights for urban slum dwellers: land tenure formalization was considered a precondition for their economic advancement, access to basic services and for urban development at large. While this is still an important and contested issue, current processes of neoliberal urbanization and world city making oblige us to look at urban land transformations from a broader perspective.

One important difference between rural and urban land grab debates is that discussions over urban land easily conflate with debates over new urban reconfigurations and gentrification processes (Shin et al., 2016). According to Clark's definition, gentrification implies a change in the population of land-users; this is a process in which "the new users are of a higher socioeconomic status than the previous users" (2005: 263). Powerful landowners worldwide can increasingly benefit from the windfalls generated by rural to urban or residential to commercial land use conversions as well as higher densities, and new zoning regulations. Smolka demonstrates that the multiplier effect of an administrative change in land use from rural to urban is typically more than 400 percent (2013: 6). Yet, López-Morales et al. (2016) urge us to also consider less straight-cut relations between landowners and real estate developers. For Latin American cities, they attest that "[t]he systematic and unequal 
appropriation of ground rent by developers leaves small landowners, tenants and multioccupants at their mercy [...]. Petty landowners are forced to sell, are short-changed for their properties and cannot afford to remain in place. Tenants experience, unilaterally, massive increases in their rent payments and are forced to leave" (López-Morales, 2016: 1101-1102).

Further inspiration from the gentrification literature can be helpful for interpreting current developments. In Smith's rent-gap thesis, places are made ready for investment through prior periods of disinvestment and devaluation (Smith, 1987). In intra-urban cases of land conversion, informal urban economies as well as land and housing arrangements are devalued in order to create new high value spaces. Shin and Kim (2016) exemplify this with the case of Seoul where they specifically analyze the speculative urbanism of South Korea's developmental state in terms of gentrification and displacement of the poor. The rent-gap thesis can also be adapted for cases of peri-urban or rural-to-urban land conversion, especially where public policy and deliberate action for creating 'world class cities' play a role. While urban land values tend to exceed rural land values, and developers, state actors, and landowners have historically profited from peri-urban land conversion, the current characteristics of urban expansion are such that deliberate value creation and speculation play a large role on top of this 'natural' value increase. In many areas around the world, rural land that has been stripped of its agricultural function (often by deliberate public disinvestment) has later been 'revalued' for urbanization and tourism (see van Noorloos, 2012). Rent gaps are thus actively created in peri-urban areas to enhance investors' and local governments' earnings on land investments. Direct and indirect displacement are therefore important to take into account.

These observations show that the land grab debate needs to go urban and that the conceptual framework of 'grabbing' itself needs to be redefined. Our attention should go beyond large-scale 'new city' projects and mega-events alone: fragmented neoliberal urbanism is still very common, for example in many of Latin America's small and medium-sized cities. New conceptualizations of inhabitance and a shift in focus from land towards a focus on real estate are helpful toward further analyzing the mixture of driving forces as well as the new tools and techniques used to appropriate land and increase its value. In the next sections we further analyze these general global trends in urban land transformations in order to reflect upon the meanings, complexities and paradoxes of such processes in terms of sustainable land governance and inclusive urban development.

\section{Investment in property: new-built and commercial gentrification}

In line with Lees et al. (2014a), we argue that any analysis of land acquisition processes in the global South requires an understanding of the contingent processes and the mutations of ruling theories and models, such as those on gentrification. Especially in the Latin American context, studies on gentrification have gained ground (e.g. Ward, 1993; Jones and Varley, 1999; Janoschka et al., 2014; Schlack and Turnbull, 2014; López-Morales et al., 2016). In general, these studies show local peculiarities that do not fit the western model of gentrification. Studies on inner cities in the global North, for example, primarily stress a class-based physical transformation. Here, working-class residents are pushed out of their neighborhoods first through 'sweat equity' investment in dilapidated housing by bohemians and later by investors and the middle class. However, scholars have also argued that gentrification in Latin American cities is not linked to the arrival of bohemians or middle-class groups with another lifestyle, but instead to a change in the functional use of buildings, as housing is often replaced by small-scale commercial activities or other functions (Ward, 1993; Jones and Varley, 1999; 1994). In Cuenca, Ecuador and Cusco, Peru, for example, gentrification of the historical center was manifested in 
the transformation of private houses into tourist facilities such as hotels, restaurants, bars, discotheques, travel agencies, shopping boutiques, internet bars and call centers (Steel, 2012; van Noorloos and Steel, 2016). In several Latin American cities we observe similar examples of commercial gentrification where land use change is related to anticipated land value increases, real estate purchases by foreigners as well as the creation of leased retail space by private investors (Schlack and Turnbull, 2014; Steel, 2012; Klaufus and Jaffe, 2015), or temporary shelter for tourists as in San Telmo in Buenos Aires (Herzer et al, 2014). 1

Apart from inner-city gentrification, gentrification processes have expanded to suburban areas and have become increasingly multi-centric (Lees et al., 2014b: 443). Al least in Latin America, there is also a growing tendency among real estate developers to gentrify the poorly-developed periphery into condominiums or gated communities for middle- and uppermiddle class residents (Coy, 2006; Alvarez-Rivadulla, 2007; Borsdorf et al., 2007; López-Morales, 2016). Angotti (2013) speaks in terms of 'enclave urbanism' as the conscious design and development of fragmented cities and metropolitan regions in Latin America. He argues that these separate enclaves contribute to "the fragmentation of urban space into exclusive, elite residential enclaves and ghettos, malls, and business districts" (Angotti, 2013:11). The same holds true for exclusive urbanization processes in other parts of the global South (De Boeck, 2011; Morange et al., 2012; Watson, 2013; Grant, 2015; Herbert and Murray, 2015). In Khartoum, for instance, the construction of gated communities in the periphery of Sudan's capital has become a popular avenue to invest petrol-dollars and other financial gains from abroad; these self-sustaining communities have little or no connection with the rest of urban life. A number of gated communities, especially on the main road to Wad Medani (including El Yasmine and Araak city), have popped up in the last decade. These high-end residential areas are developed by Sudanese real estate companies working together with investors from the Gulf states or the Maghreb. The real estate prices of simple condominiums and so-called 'town houses' easily cost up to 400,000 US dollars. These villas are only affordable to the political and business elite including parts of the Sudanese diaspora who work in the Gulf States; they invest in these real estate projects to earn rental income from foreigners working for international NGOs and embassies (Crombé, 2009; Choplin and Franck, 2014: 62).

In other words gentrification in the global South has evolved towards new manifestations of urban development that are related to an often expected rise of land and other real estate prices. This has resulted in highly visible forms of socio-spatial segregation between those who have access to urban land and those who do not. Johnny Miller's aerial photography project titled Unequal scenes shows how differential access to land in South Africa results in visible segregation. 2 This segregation, more complex and fragmented than before, is no longer uniquely dominated by income standards; an important generational component has been introduced. Many young families can no longer afford to buy urban property and so rely on rental markets or the informal housing sector. In addition, these land markets have become increasingly exclusive as real estate brokers and investors prioritize homogenous neighborhoods by selling and renting property to foreigners and urban elites.

\footnotetext{
${ }^{1}$ Similar processes have also been observed outside Latin America in regions where tourism or lifestyle migration are prominent, but the term gentrification is hardly used in these contexts (an exception is provided by Van Laar et al., 2013 on South Africa).

2 www.unequalscenes.com
} 
These particularities of urban regeneration and spatial gentrification are important for the development of new lines of research on the urban land grab and the multiple struggles of control over, and ownership of, urban space. Scholars typically focus on the urbanization of rural areas, urban sprawl, and peri-urban land grabs. However, unless we recognize that gentrification can also signal underlying processes of land grabs, we miss out on these cases that are important to achieve a more complete and comparative overview of worldwide urban land grabbing. Shin and Kim (2016) for instance argue that the concept of redevelopment and demolition are widely spread in the popular vernacular in Korea, but that in the end gentrification is what municipalities aim for in their attempts to generate investment windfalls. The same holds true for the India cases studied by Doshi (2014). Here the term gentrification is rarely used in popular and academic discourses despite the fact that urban land transformations often entail aspects of gentrification and rising land values. These aspects include capital (re)investment, commodification and the displacement of vulnerable groups to make room for infrastructure and luxury real estate geared toward meeting the needs of elites and the uppermiddle classes. Hence, the interconnectedness of land use change and the subsequent increase of land and property values, paired with new residents or user groups, demonstrate that gentrification processes and the urban land grab cannot be considered separately. In the next section we focus on another type of city investment, namely investment in public spaces and services and how it can result in unintended processes of gentrification and land commodification.

\section{Investment in public spaces and services: land value increase as a side effect}

Many urban renewal projects are steered by global urban agendas. Since the 1996 Habitat Conference in Istanbul, many city administrations and local governments have taken great pains to promote a more sustainable and compact city model. They have also restructured historical but dilapidated inner cities, and have exchanged successful policy instruments. With increasing international attention placed on successful examples of local public policies, unintended displacements and unexpected new inequalities tend to be overlooked for the greater good. Theorizing on the discrepancies between planning, governance and administration on one hand and survival on the other, Watson speaks of a 'conflict of rationalities' as way to understand "why, so often, sophisticated and 'best practice' planning and policy interventions have unintended outcomes" (2009: 2272).

Take for example the Latin America city of Curitiba in Brazil, one of the most commonly cited on best-practices lists. The urban renewal policies initiated by three-time mayor Jaime Lerner in the 1970s and 1980s became internationally famous; as a result, the city was bestowed with the title of 'First-World city' in the global South and considered to be the "most livable city in the world" (Macedo, 2004: 540). One of the interventions that contributed to this mythic image was the policy to substantially increase the size of the city's green areas in parks and woodlands. This policy measure was part of a coherent set of land policies that aimed to reduce environmental hazards caused by flooding and traffic jams (Rabinovich, 1992). Although the high amount of public space per inhabitant is generally interpreted as one main aspect of sustainable land governance (The Economist Intelligence Unit, 2010), critical scholars have pointed out that the construction of parks resulted in a rise of real estate prices in the adjacent areas and thus gentrification (Irazábal, 2004: 152; Macedo, 2013). Although unintended, the pursuit of healthy, livable and resilient cities resulted in speculative urbanism. Irazábal concludes that while the "disfranchised residents of Curitiba's metropolitan area have never 
visited its parks", the creation of the parks has helped to "create or consolidate wealthy neighborhoods or allow the gentrification of other important areas" (2004: 152).

The Curitiba example clearly shows that capital accumulation in urban areas, gentrification processes and extreme inequality can be initiated by land governance interventions and actors that differ completely from those typically associated with the rural land grab. In this example, it is not multinationals or foreigners that acquire large amounts of land for agriculture, mining, infrastructure or tourism, but an ambitious mayor and generations of urban planners whose work has been highly appreciated worldwide. Nevertheless, an increase of land and property values and the subsequent displacement of sitting residents was one of the outcomes however unintended. The same can be said in the case of Medellín, where integrated local projects (PUIs) were executed in the most vulnerable urban areas to break the downward circles of violence and destitution. Although mayors Fajarado and Salazar were internationally heralded for 'fighting crime with architecture', critics have pointed out that the large investments in architectural icons, which attracted tourists and paved the way for the international events and the title 'Most Innovative City in the World' (granted in 2012 by the Urban Land Institute), could possibly result in increases in the value of real estate and displacement. Scholars disagree about the impact of the plans on local communities (Brand, 2013; Martin and Martin, 2015; Samper and Marko, 2015). The consequences of land value increases and the dilemma over whether or not improvements in public land and infrastructure access can counterbalance the negative effects is highly debated, especially in the land value capture debate (Smolka, 2013). In the next section we focus on urban investments that envision value increases in the future and the ways in which they interrelate with speculative urbanism.

\section{Investment in image and futures: 'Bubble urbanism'}

Urban and peri-urban land investment is often about speculation, worlding and image building rather than physical constructions alone. Indeed, speculative strategies are gaining influence in urban landscapes across the global South. In Africa, world city making through urban regeneration and new cities is increasingly promoted mostly by private investors and central state governments (which are highly influenced by transnational investors and donors), and in some cases also by city governments (e.g., Cirolia, 2014 for the case of Cape Town, South Africa and Otsuki et al., 2016 for the case of Beira, Mozambique). In Latin America we also find an increased incidence of powerful city governments engaging in worlding strategies: Colombian cities for example are claiming their position on the world map. The large-scale urban redevelopments in Brazil, such as for the 2014 World Cup and the 2016 Olympic Games in Rio de Janeiro, have also attracted worldwide attention as largely speculative worlding strategies causing displacement (Gaffney, 2010; Jacobs, 2013; Menezes, 2015).

Another striking phenomena in rapidly-urbanizing regions is the construction of massive, low-cost housing such as in the Casas Geo projects in Mexico. The houses in these projects are designed to serve what the GEO Corporation defined as the 'average Mexican' family (Inclán-Valadez, 2015). With up to 15,000 housing units, the scale of these projects is unprecedented. In fact, over 2.4 million Mexicans are now living in a Casas Geo house (Corporación GEO, 2015). The development project covers land acquisition, design, construction, mortgage allocation, marketing and sales or post-sales services (Inclán-Valadez, 2015). The majority of these projects are located in peri-urban areas; the objective is to generate interest by focusing on the suburban lifestyle. Stimulated by the Mexican public policy framework on housing and credit, the Geo Corporation converted communal agrarian ejido lands into urban residential areas though large-scale land acquisitions. Homeowners have been strategically 
included in the project as 'co-producers' or 'partners' instead of customers. This enables the company to construct only the basic framework, a carcass that is not yet ready to live in, leaving the upgrading activities needed for a minimum comfort level up to the homeowners. Although the titling and the legalization of former communal land does not necessarily induce the displacement of people (Varley, 2016), the Casas GEO method clearly connects land acquisition with rural-to-urban transformation, urban real estate markets, and increasing land values through the creation of an American suburban image. This Mexican example case exemplifies a broader speculative trend in urbanism in which investments in image building and city branding are paramount; such investments have appeared in various forms in different parts of the world.

The concept of speculative urbanism offers an original angle through its focus on the risks and speculative aspects of urban land-based investments. Goldman (2011), for instance, explains how Bangalore, India has been remade into a 'world city' by the local government and parastatals' speculative land development strategies in peri-urban areas. Transforming rural agricultural economies into urban real estate economies through land speculation - and use of international financing - has been the main activity; although leading to quick profits, dispossession of previous inhabitants has also resulted. The speculative aspect of this new form of urbanism - besides being based on debt financing - lies in its lack of connection to the 'real' economy: many new 'world class infrastructure' projects are not profitable investments in themselves, but are rather investment bubbles used to create a world city image that attracts additional investment. A new airport in Bangalore was not built because of any long-term strategy or expected need, but purely to enhance local land values and to create momentum for new investment in high-scale residential communities, medical hotels and business parks (Goldman, 2011). In China, the rapid urbanization strategies of local states can be placed under the same umbrella. Local governments use a variety of projects such as 'new city', 'eco-city' and 'university town' to generate land-related profits. For example, university towns are mushrooming all over the country; this is a speculative strategy meant to raise the value of the surrounding area (called 'high quality spaces') so that the local state can further profit from land speculation (Li et al., 2014). The same processes can be observed in Dubai where the quest at the city level for symbolic power and the need to be counted as a 'global city' has resulted in a vertically-oriented built space characterized by skyscrapers, modern shopping malls, and the longest automated metro-line in the world (Acuto, 2010). In more general terms, local governments, parastatal officials, and the private sector are reaping the short-term rewards and financial revenues from land and city image building. The main goal is to compete with other 'world cities': as cities increasingly inter-reference, speculative urbanism seems to be the new model of urban governance that depends on circulating ideas, finance, and capital flows (Goldman, 2011; Bunnell, 2015; Shin and Kim, 2016).

Speculative urbanism has emerged as an Asian concept related to a specific type of governance. Yet debt financing, short-term profit orientation, worlding and image building as well as the lack of connection to real economies and the creation of 'bubbles' can inform current understandings of urbanism and the role of land in Asia, Latin America and Africa. Speculative urbanism takes place in areas where 'real life' economic transformation and the creation of the middle class - in other words a transformation that is endogenous and structural - is either largely absent (such as in many African cities) or remains rather separated from the urban speculation process (as in Asia's urban economies). It thus prioritizes image over actual needs and growth; it also uses world city image building as a short-term and speculative growth strategy. Especially in African cities where the formal economic base is relatively thin, 
speculative strategies seem even more empty and less connected to any real growth in the broader urban economy (Potts, 2012; Turok, 2014).

Recent city renewal and new city projects in Africa for instance are likely to rely heavily on transnational elites, expats and diaspora who can afford to invest in luxury lifestyles; as such, local economic or middle-class growth is not a necessary precondition. For instance, la Cité du Fleuve, financed by a group of international private investors and inspired by Dubai, is an exclusive development that is situated on two artificially-created islands in Kinshasa, DRC. According to De Boeck, it is a huge, gated community that created a consumptive enclave for the rich so that, "once more, most people currently living in the city will never be able to set foot on the two islands" (2011: 277). Many of the area's fishermen and city farmers who carve out vulnerable livelihoods have been or will be displaced (De Boeck, 2011). Moreover, such urbanization strategies are mirrored by broader city government policies aiming to 'clean the city' of less-desirable and informal structures, businesses, and 'bodies' (De Boeck, 211:.273). Despite being announced, many new city projects have not yet moved beyond a first speculative phase; these include Hope City in Ghana and Modderfontein New City near Johannesburg in South Africa (see also Watson, 2013). Such projects thus lead to empty urban bubbles characterized by high speculation, temporariness and absenteeism (see Shin and Kim, 2016). In the absence of actual productive development and innovation that new cities promise to provide, the consumptive, speculative and spectacular aspects predominate (van Noorloos and Kloosterboer, forthcoming). In the meantime, land values are increasing and a variety of actors including well-connected local politician-landowners and businesses - are intent on reaping the profits.

Latin America also has its share of such externally-dependent and speculative urban projects, although at a smaller scale (van Noorloos and Steel, 2016). Similar to African projects (but different from many Asian worlding projects), they are often driven by the private sector within the context of weak local governance. Gated communities in particular come in all types and sizes; they include large, urban and all-inclusive (see Janoschka, 2003 for Argentina) as well as many smaller or more diversified types. For example, destinations for residential tourism and lifestyle migration include the northwest coast of Costa Rica and many areas of Mexico. Here, gated communities have sprung up to satisfy mostly American and Canadian demands for luxury housing in affordable places and healthy and 'relaxed' lifestyles. However, speculation and supply-driven growth was part and parcel of these projects. In fact the latest economic crisis has clearly exposed this aspect: many constructions were left unfinished and buildings were left empty (van Noorloos, 2012).

\section{Conclusion: new avenues for research}

In this article we have provided an overview of a few central topics that are important when the urban dimension of the global land grab debate is analyzed; they include concepts such as land use change, gentrification, speculative urbanism, and the worlding of cities. We have indicated how the commercialization of urban land is taking different forms and shaping different (and often unpredicted) types of investments and outcomes. The main differences dividing studies on rural land grabs and those that explore land grabs in urban contexts have been summarized in Table 1; it illustrates that in the urban cases there is no unilineal transfer of local control over land towards more powerful outsiders. Moreover, urban land grabbing is the result of a plethora of actors; the role of public policies cannot be ignored. An increase of land and other real estate values tends to lead to an exclusion of poor and young residents from the most attractive living areas in the city. In the same manner, investments in public space and public services such as 
parks, squares and transport infrastructure have resulted in skyrocketing real estate and land prices although they have not necessarily been constructed for this purpose. A third manifestation of urban investments does aspire to achieve increases in value, but not through physical construction projects. Instead of relying on concrete investments in housing and commercial building infrastructure, this strategy counts on the symbolic power of image building and city branding in order to trigger value increases in land based on a 'promise'. While an appealing project alone may lure investors, over time they may ultimately be faced with an unfinished project, empty land as well as absentee owners and users.

On the basis of these findings, we can formulate concrete avenues for future research on urban land grabs in the global South. First, as urban development inevitably entails land-based investments and we want such investments to be more inclusive and participatory, we need to carefully map out the processes as well as the direct and indirect outcomes of different urban land investments. Research should take into account the complex patchwork of urban land acquisitions and their diverse temporalities. New lines of inquiry should thus acknowledge the discordance that currently exists between short-term investments in land and long-term investments, for example real estate and services on one hand (upgrading of public services and gentrification of housing and commerce) and investment in world city images and publicity on the other where the actual building or use of the projects has a longer-term horizon that might never be realized.. 3 These complex temporalities intersect with the diversity of spatialities of current urban land investments, and range from inner-city upgrading to tabula rasa approaches to new city strategies. As we have shown, analyzing land grab processes in urban areas can be fruitful for gaining a more in-depth understanding of contemporary phenomena such as speculative urbanism and global-South forms of gentrification. On the other hand, conceptualizing current urban processes through the lens of urban land grabbing adds the extra dimension of land; this is increasingly viewed as central as actual and perceived land scarcity is key toward understanding current urban strategies and their consequences which extend beyond the urban realm. Indeed, the interconnectedness of the urban and the rural is key. The concept of gentrification alone cannot capture the entire variety of exclusionary urban processes nor the important role that land plays in these developments.

The urban land grab agenda also needs to connect topics such as land formalization, land access, and user displacement to the layered realities of horizontal ownership (condominiums), absentee ownership, trans-nationalization of land rights and the increased influence of brokers and middlemen in establishing and mediating land rights. Who wins and who loses is less straightforward in this context of hybrid forms of urban land acquisition. While unfinished construction and empty buildings might be the result of speculation that lacks a connection to the real economy, it might also bring new forms of customary tenure and land dynamics. In Sudan for instance vacant plots of private land and unfinished constructions have given 'home' to many refugee families and internally-displaced people who temporarily guard the grounds or the buildings under construction. It is especially these types of urban dynamics - and globalization from below - that deserve more attention in future research as they can bring light to the paradoxes and different layers of urban land issues. They make way for a kaleidoscopic perspective on the urban land grab debate by uncovering the multiple and often unpredicted ways in which urban dwellers try to access and gain control over urban land.

\footnotetext{
${ }^{3}$ However, the temporalities of capital may be contradictory. For instance, investments in speculative image building may still rely on quick capital and with expectations of short-term returns on investment.
} 
City governments have a leading role in governing land and mediating urban land conflicts but can only do so in close cooperation with other national and transnational actors, which may include the private sector. Indeed, city governments are increasingly under the influence of transnational corporations, global finance, and international brokers such as consultants, real estate investors and architects. In addition, we are witnessing an increasing trend of transferring 'best practices' into new urban contexts at a global scale. Hence it should be further analyzed how such new flows of finance, ideas and knowledge can be proactively used by city governments to solve very urgent urban issues as opposed to enhancing neoliberal urbanization 'from above' (Sheppard et al., 2015) or inadvertently contributing to gentrification and new inequalities in access to land. Following Habitat III, the renewed attention for land value capture, at least in Latin America, can be a promising start (Blanco et al., 2016). City governments will have to deal with the complexities and paradoxes of urban land governance, making evaluations and recommendations increasingly complex.

\section{References}

Acuto, M. (2010). High-rise Dubai urban entrepreneurialism and the technology of symbolic power. Cities 27, 272-284.

Alvarez-Rivadulla, M. J. (2007). Golden ghettos: gated communities and class residential segregation in Montevideo, Uruguay. Environment and Planning A 39(1), 47-63.

Amin, A. and Thrift, N. (2002). Cities: Reimagining the urban. Cambridge, U.K.: Polity.

Angotti, T. (2013). Urban Latin America: violence, enclaves, and struggles for land. Latin American Perspectives 40 (2), 5-20.

Blanco, A., V. Fretes Cibils and A. Muñoz (2016). Expandiendo el uso de la valorización del suelo: La captura de plusvalías en América Latina y el Caribe, Inter American Development Bank, Washington, D.C.

Borsdorf, A., Hidalgo, R., and Sanchez, R. (2007). A new model of urban development in Latin America: the gated communities and fenced cities in the metropolitan areas of Santiago de Chile and Valparaíso. Cities 24, 365-378.

Brand, P. (2013). Governing inequality in the South through the Barcelona model: 'social urbanism' in Medellín, Colombia. Paper addressed at seminar Interrogating Urban Crisis: Governance, Contestation, Critique, 9-11 September, Leicester: De Montfort University.

Brenner, N. (2013). Theses on urbanization. Public Culture 25 (1), 85-114, DOI 10.1215/08992363- 1890477.

Brenner, N. and Schmid, C. (2014). The 'Urban Age' in Question. International Journal of Urban and Regional Research 38 (3), 731-55.

Bromley, R. and Mackie, P. (2009). Displacement and New Spaces for Informal Trade in the Latin American City. Urban Studies 46(7), 1485-1506.

Bunnell, T. (2015). Antecedent cities and interreferencing effects: Learning from and extending beyond critiques of neoliberalisation. Urban Studies 52 (11), 1983-2000.

Choplin, A. and Franck, A. (2014). Seeing Dubai in Khartoum and Nouakchott: 'gulfication' on the margins of the Arab world. In S. Wippel, K. Bromber, C. Steiner and B. Krawietz (Eds.), Under construction: logics of urbanism in the Gulf Region. London: Ashgate (pp. 271-284).

Cirolia, L.R. (2014). (W)Escaping the Challenges of the City: a Critique of Cape Town's Proposed Satellite Town. Urban Forum 25, 295-312. 
Clark, E. (2005). The order and simplicity of gentrification. In R. Atkinson and G. Bridge (Eds.) Gentrification in a global context. The new urban colonialism. London/ New York: Routledge (pp.261-269).

Corporación GEO (2015). Informe Annual 2014. Available from http://www.corporaciongeo.com/informacion-para-accionistas/informes-anuales-circular\%C3\%9Anica.aspx?menu=4 (accessed 10 May 2016).

Coy, M. (2006). Gated communities and urban fragmentation in Latin America: the Brazilian experience. GeoJournal 66, 121-132.

Crombé, L. (2009) Building Khartoum's future? At http://www.espacestemps.net/articles/building-khartoum-future/ (blog consulted 7 June 2016).

De Boeck, F. (2011). Inhabiting ocular ground: Kinshasa's future in the light of Congo's spectral urban politics. Cultural Anthropology 26 (2), 263-286.

Doshi, S. (2014). Rethinking gentrification in India: displacement, dispossession and the spectre of development. In L. Lees, H. Bang Shin and E. López-Morales (Eds.), Global gentrifications. Uneven development and displacement. Bristol, University of Bristol; Chicago, University of Chicago Press.

Gaffney, C. (2010). Mega-events and socio-spatial dynamics in Rio de Janeiro, 1919-2016. Journal of Latin American Geography, 9 (1), 7-29.

Gilbert, A. (2015). Urban governance in the South: How did Bogota lose its shine? Urban Studies $52(4), 665-684$.

Goldman, M. (2011). Speculative urbanism and the making of the next world city. International Journal of Urban and Regional Research 35 (3), 555-581.

Grant, R. (2015). Sustainable African Urban Futures. Stocktaking and Critical Reflection on Proposed Urban Projects. American Behavioral Scientist 59(3), 294-310.

Gudynas, E. (2008). The New Bonfire of Vanities: Soybean cultivation and globalization in South America. Development 51(4), 512-518.

Herbert, C.W. and Murray, M.J. (2015). Building from Scratch: New Cities, Privatized Urbanism and the Spatial Restructuring of Johannesburg after Apartheid. International Journal of Urban and Regional Research 39(3), 471-494. doi: 10.1111/1468-2427.12180

Herzer, H., Di Virgilio, M. M. and Rodríguez, M.C. (2014). Gentrification in Buenos Aires: global trends and local features. In L. Lees, H. Bang Shin and E. López-Morales (Eds.), Global gentrifications. Uneven development and displacement. Bristol, University of Bristol; Chicago, University of Chicago Press.

Hilhorst, T., Nelen, J. and Traoré, N. (2011). Agrarian change below the radar screen: Rising farmland acquisitions by domestic investors in West Africa. Results from a survey in Benin, Burkina Faso and Niger. Paper by LANDac, Royal Tropical Institute and SNV (April 2011). Accessed 6 July, 2016 at http://www.bibalex.org/Search4Dev/files/419112/442087.pdf

Holmes, G. (2014). What is a land grab? Exploring green grabs, conservation, and private protected areas in southern Chile. Journal of Peasant Studies, 41(4), 547-567.

Inclán-Valadez, C. (2015). Living with style in my Casa GEO: Large-scale housing conjuntos in urban Mexico. In C. Klaufus and A. Ouweneel (Eds.), Housing and Belonging in Latin America. Oxford, New York: Berghahn (pp. 181-206).

Irazábal, C. (2004). Architecture and the production of postcard images: Invocations of tradition vs. critical transnationalism in Curitiba. In N. AlSayyad (Ed.), The End of Tradition? London: Routledge, pp. 144-168. 
Jacobs, E. (2013). In the Shadow of Glory: Olympic Pageantry and the Disruption of Rio's Favelas. Anthropology Senior, 143. University of Pennsylvania: Pennsylvania.

Janoschka, M. (2003). Nordelta - Ciudad cerrada. El Análisis de un nuevo estilo de vida en el gran Buenos Aires. Scripta Nova, Revista Electrónica de Geografía y Ciencias Sociales Vol. VII, num. 146(121).

Janoschka, M., Sequera, J., and Salinas, L. (2014). Gentrification in Spain and Latin America - a critical dialogue. International Journal of Urban and Regional Research, 38(4), 1234-1265.

Jones, G. and Varley, A. (1994). The Contest for the City Centre: Street Traders versus Buildings. Bulletin of Latin American Research 13 (1), 27-44.

Jones, G., and Varley, A. (1999). The reconquest of the historic centre: urban conservation and gentrification in Puebla, Mexico. Environment and Planning A 31(9), 1547-1566.

Klaufus, C. (2010). Watching the city grow: Remittances and sprawl in intermediate Central American cities. Environment and Urbanization 22(1), 125-137.

Klaufus, C. and Jaffe, R. (2015). Latin American and Caribbean Urban Development. European Review of Latin American and Caribbean Studies 100, 63-72.

Lees, L., Bang Shin, H. and López-Morales, E. (Eds.) (2014a). Global gentrifications. Uneven development and displacement. Bristol, University of Bristol; Chicago, University of Chicago Press.

Lees, L., Bang Shin, H. and López-Morales, E. (2014b). Conclusion: global gentrifications. In L. Lees, H. Bang Shin and E. López-Morales (Eds.), Global gentrifications. Uneven development and displacement. Bristol, University of Bristol; Chicago, University of Chicago Press.

Li, Z., Li, X. and Wang, L. (2014). Speculative urbanism and the making of university towns in China: A case of Guangzhou University Town. Habitat International 44, 422-431.

López-Morales, E., Shin, H. B. and Lees, L. (2016). Latin American gentrifications. Urban Geography, 37:8, 1091-1108.

Macedo, J. (2004). City Profile: Curitiba. Cities 21(6), 537-549.

Macedo, J. (2013). Planning a sustainable city: The making of Curitiba, Brazil. Journal of Planning History 12(4), 334-353.

Margulis, M.E., N. McKeon and S.M. Borras (2013). Land gabbing and global governance: critical perspectives. Globalizations 10(1), 1-23.

Martin, G. and Martin, M. (2015). Proximity, crime, politics and design: Medellín's popular neighbourhoods and the experience of belonging. In C. Klaufus and A. Ouweneel (Eds.), Housing and Belonging in Latin America.. Oxford, New York: Berghahn (pp. 43-78).

Menezes, P. (2015). Favela Modelo: a study on housing, belonging and civic engagement in a pacified Favela in Rio de Janiero, Brazil. In C. Klaufus and A. Ouweneel (Eds.), Housing and Belonging in Latin America. Oxford, New York: Berghahn (pp. 123-148).

McFarlane, C. (2010). The Comparative City: Knowledge, Learning, Urbanism. International Journal for Urban and Regional Studies 34 (4), 725-742.

Morange, M., Folio, F., Peyroux, E. and Vivet, J. (2012). The spread of a transnational model: 'gated communities' in three Southern African cities (Cape Town, Maputo and Windhoek). International Journal of Urban and Regional Research 36(5), 890-914.

Ortiz, C. (2016) 'Medellín urban forums: Transnational assemblages of hegemonic and counterhegemonic narratives', Paper presentation at the international Latin American Studies Association conference, New York, 30 May.

Otsuki, K., Read, M. and Zoomers, A. (2016). Large Scale Investments in Infrastructure: Competing Policy regimes to Control Connections. Paper for International Institute of Social Studies (ISS) International Colloquium: Global governance/politics, climate justice \& 
agrarian/social justice: linkages and challenges. Available from http://www.iss.nl/fileadmin/ASSETS/iss/Research and projects/Research networks/ICAS/ 32-ICAS CP Otsuki et al.pdf (accessed 19 April 2016).

Parnell, S. (2016). Defining a Global Urban Development Agenda. World Development 78, 529540.

Pieterse, E. and Parnell, S. (2014). Africa's urban revolution in context. In S. Parnell and E. Pieterse (Eds.), Africa's urban revolution. London: Zed Books (pp. 1-17).

Potts, D. (2012). Challenging the Myths of Urban Dynamics in Sub-Saharan Africa: The Evidence from Nigeria. World Development 40 (7), 1382-1393.

Rabinovich, J. (1992). Curitiba: Towards urban sustainable development. Environment and Urbanization 4(2), 62-73.

Roberts, B. (2005). Globalization and Latin American Cities. International Journal of Urban and Regional Research 29 (1), 110-23.

Robinson, J. (2006). Ordinary Cities: Between Modernity and Development. London: Routledge.

Roy, A. and Ong, A. (2011) (Eds). Worlding Cities: Asian Experiments and the Art of Being Global. Malden, MA., Wiley-Blackwell.

Samper, J. and Marko, T. (2015). (Re)Building the City of Medellín: Beyond State Rhetoric vs.

Personal Experience - A Call for Consolidated Synergies. In C. Klaufus and A. Ouweneel (Eds.),

Housing and Belonging in Latin America. Oxford, New York: Berghahn (pp. 241-271).

Schlack E. and Turnbull, N. (2014). Emerging retail gentrification in Santiago de Chile: the case of Italia-Caupolicán. In L. Lees, H. Bang Shin and E. López-Morales (Eds.), Global gentrifications. Uneven development and displacement. Bristol, University of Bristol; Chicago, University of Chicago Press.

Sheppard, E., Gidwani, V., Goldman, M., Leitner, H., Roy, A. and Maringanti, A. (2015). Introduction: urban revolutions in the age of global urbanism. Urban Studies 52 (11), 19471961.

Shin, H.B. and Kim, S. (2016). The developmental state, speculative urbanisation and the politics of displacement in gentrifying Seoul. Urban Studies 53(3), 540-559.

Shin, H.B., Lees, L., and López-Morales, E. (2016). Introduction: Locating gentrification in the global east. Urban Studies, 53(3), 455-470.

Sklair, L. (2005). The Transnational Capitalist Class and Contemporary Architecture in Globalizing Cities. International Journal of Urban and Regional Research 29(3), 485-500.

Smith, N. (1987). Gentrification and the Rent Gap. Annals of the Association of American Geographers, 77, 462-465.

Smith, N. (1996). The new urban frontier: Gentrification and the revanchist city. New York: Routledge.

Smolka, M. (2013). Implementing Value Capture in Latin America: Policies and Tools for Urban Development. Policy Focus Report. Cambridge, MA: Lincoln Institute of Land Policy.

Soja, E. W. (2010). Seeking Spatial Justice. Minneapolis: University of Minnesota Press.The Economist Intelligence Unit (2010). Latin American Green City Index: Assessing the environmental performance of Latin America's major cities. München: Siemens AG.

Steel, G. (2012). Whose Paradise? Itinerant Street Vendors' Individual and Collective Practices of Political Agency in the Tourist Street of Cusco, Peru. International Journal of Urban and Regional Research 36(5), 1007-21.

Turok, I. (2014). Linking urbanisation and development in Africa's economic revival. In S. Parnell and E. Pieterse (Eds.), Africa's urban revolution. London: Zed Books (pp. 60-81).

United Nations Department of Economic and Social Affairs, (UN DESA) (2014). World Urbanization Prospects. The 2014 revision, highlights. New York: UN DESA. 
UN-Habitat (2012). State of Latin American and Caribbean Cities: Towards a New Urban Transition. Nairobi: UN-Habitat.

Van Laar, S.; Cottyn, I.R.R.J.B.; Donaldson, R.; Zoomers, A. and Ferreira, S. (2013). 'Living apart together' in Franschhoek, South Africa: the implications of second-home development for equitable and sustainable development. In M. Janoschka and H. Haas (Eds.) Contested Spatialities, Lifestyle Migration and Residential Tourism. London/New York: Routledge (pp. 190-204).

van Noorloos, F. (2012). Whose place in the sun? Residential tourism and its implications for equitable and sustainable development in Guanacaste, Costa Rica. PhD thesis Utrecht University. Delft: Eburon.

van Noorloos, F. and Kloosterboer, M. (forthcoming). Africa's new cities: The contested future of urbanization. Urban Studies, accepted.

van Noorloos, F. and Steel, G. (2016). Lifestyle migration and socio-spatial segregation in the urban(izing) landscapes of Cuenca (Ecuador) and Guanacaste (Costa Rica). Habitat International 54 (1), 50-57.

Varley, A. (2016). From informal urbanism to gentrification in Mexico: a new colonialism?. CEDLA Lecture, Amsterdam, 11 March.

Ward, P. (1993). The Latin American inner city: differences of degree or of kind? Environment and Planning A 25(8), 1131-1160.

Watson, V. (2009). Seeing from the South: Refocusing Urban Planning on the Globe's Central Urban Issues. Urban Studies 46 (11), 2259-2275.

Watson, V. (2013). African urban fantasies: dreams or nightmares? Environment and Urbanization 26 (1), 215-231.

Zoomers, A. (2010). Globalisation and the foreignisation of space: Seven processes driving the current global land grab. The Journal of Peasant Studies, 37(2), 429-447.

Zoomers, A., and Kaag, M. (2014). Conclusion: Beyond the global land grab hype - ways forward in research and action. In M. Kaag, \& A. Zoomers (Eds.), The global land grab: Beyond the hype. London: ZED Books (pp. 201-216).

Zoomers, A., van Noorloos, F., Otsuki, K., Steel, G. and van Westen, G. (2017). The Rush for Land in an Urbanizing World: From Land Grabbing Toward Developing Safe, Resilient, and Sustainable Cities and Landscapes. World Development 92, 242-252.

\section{Acknowledgements}

This study benefited from the support of LANDac, the Netherlands Land Academy, which works on land governance for equitable and sustainable development. We are also grateful to Prof. Dr. Annelies Zoomers, Dr. Kei Otsuki and Dr. Robert Fletcher for coordinating this special issue as well as to the three anonymous reviewers for their valuable comments. 